\title{
A Study on Industry Superannuation in Australia: Risk Disclosure and Pre-Global Financial Crisis
}

\author{
Diane Kraal $(\mathrm{PhD})$ \\ Lecturer, Department of Business Law and Taxation \\ Monash University \\ Caulfield East, Australia 3145 \\ P. W.S. Yapa (PhD) (Corresponding author) \\ Associate Professor in Accounting \\ School of Accounting, RMIT University \\ Melbourne Australia 3000 \\ Tel: 61-3-9925-1606 E-mail:prem.yapa@rmit.edu.au,
}

Received: June 25, 2011 Accepted: October 27, $2011 \quad$ Published: June 1, 2012

doi:10.5296/ajfa.v4i1.744 URL: http://dx.doi.org/10.5296/ajfa.v4i1.744

We would like to acknowldege participant comments on this paper that was presented as 'An Exploratory Study on Quantitative and Qualitative Disclosures by Australian Superannuation Funds with Accounting Standard AASB 7', 32nd Annual Congress of the European Accounting Association, Tampere, Finland, 23-25 May2009. We also wish to thank the respondents for their support in providing data for this study.

\begin{abstract}
The purpose of this paper is to examine the extent to which the statutory accounts of industry superannuation funds reported risk in 2007, required by the new Australian accounting standard AASB 7-Financial Instruments: Disclosures. This study tests our selected methodologies to measure risk disclosure. The sample was randomly selected on the list of industry superannuation funds published by APRA. In 2007, there were 74 industry superannuation funds. However, the detailed data published showed only the largest 58 industry super funds. Our sample was 44 industry super funds and the response rate was 59 per cent. The findings indicated the trend of low levels of risk disclosure for 2007, the year
\end{abstract}




\section{Macrothink}

Asian Journal of Finance \& Accounting ISSN 1946-052X 2012, Vol. 4, No. 1

before the onset of the Global Financial Crisis. The study is limited as the data was collected using email requests for published financial data. This paper should also be of interest to the professional community as it investigates primary financial data that is 'tightly held' by superannuation funds, that is, data that is not readily available on websites. This research will contribute toward determining if $A A S B 7$ has improved the quality of financial data available to fund members and other interested external parties.

Keywords: Australian Industry Super-funds, AASB 7, Global Financial Crisis, risk disclosure. 


\section{Introduction}

In the wake of the Global Financial Crisis (GFC) stakeholders have voiced concerns about the stability of superannuation funds in Australia. ${ }^{1}$ Superannuation can be described as monies invested during one's productive working life to return as a lump sum or an income stream upon retirement. Superannuation schemes have been available to select company employees since Australia's Federation and later on to public servants. In the 1960s and 70s employer-sponsored superannuation was made available to 'executive' employees, a grouping which excluded most women.

The enhanced reporting required by the new Australian accounting standard AASB 7 Financial Instruments: Disclosures is timely as it addresses the need for more information on risk. The superannuation industry in particular, has had a culture of conservatism in the area of disclosure. Although superannuation has been reformed by the passage of the 'simpler super' legislation, the way in which billions of funds are invested or managed for millions of Australians is still not widely understood. ${ }^{2}$ Hence this paper on super fund risk disclosure should be of interest to external parties, who may have concerns about governance in this sector, and particularly to investors many of whom are attracted to superannuation because of the tax concessions.

This paper is an exploratory study and aims to test our selected methodologies to measure risk disclosure. The intent is to examine the extent to which the statutory accounts of a sample of industry superannuation funds in 2007 disclosed data on risk. The data is analysed via a triangulation of methods: a ratings assessment; descriptive statistics where frequencies were determined about qualitative and quantitative risk disclosure; and finally via a content analysis of descriptions of risk mitigation.

It was decided that our research would take the form of an exploratory study as a result of difficulties in gaining copies of full financial statements from a number of industry superannuation funds we first approached. The best option was to test our methodological techniques on a small sample of data. With the results of this research we intend to enlarge this sample by re-contacting super funds and once more request data on the basis that we can provide useful information to industry. It is therefore envisaged that the results of this research will be enlarged in the post-exploratory stage to form the first year of comparative information for a longitudinal study in the future.

\footnotetext{
${ }^{1}$ An Association of Superannuation Funds in Australia survey notes that 'a high 65 percent of respondents in total doubt the stability of super tax arrangements, with 36 percent indicating they believe tax arrangements will be quite different when they retire, and 29 percent believing they will be very different'. See: http://www.superannuation.asn.au/mr101108/default.aspx (accessed 23/11/10).
}

A stakeholder may be: a consumer, employee, investor, researcher, a community group, government regulator, or simply an interested individual.

2 Tax Laws Amendment (Simplified Superannuation) Act 2007 and related legislation received Royal Assent on 15 March 2007. 
As a result of the GFC much more focus is being placed on issues such as going concern viability and how organisations will survive the downturn. Nervous superannuation investors are also evaluating their investments more carefully. Mike Lynn, vice president for investor relations at Woodside Petroleum, says: 'Given the turmoil of recent times, we may see more companies paying greater attention to discussing their risks, their debt/funding situations and the outlook for their sectors...' 'Lynn believes the GFC has prompted investors to seek information that relates to the company's ability to fund its work programs, its debt funding arrangements and its exposure to credit risk. ${ }^{4}$ Although Lynn's words are directed to companies, his unease could equally be addressed to super funds.

This paper should also be of interest to the professional community as it investigates primary financial data that is 'tightly held' by superannuation funds, that is, data that is not readily available on websites. It took many emails and follow up phone calls to gain copies of full statutory financial accounts for our sample of super funds. Our research fills a gap by analysing and reporting this primary data.

It is envisaged that our research will contribute toward determining if $A A S B 7$ has improved the quality of financial data available to fund members and other interested external parties. As this study is limited to a sample of large industry super funds one of the outcomes of this research will be to flag the need to review and strengthen the standard of quantitative and qualitative reporting for superannuation funds in Australia.

The remainder of the paper is organised as follows. In section 2 the research question is explained. The literature review is provided in section 3. Section 4 explains the methodology. Industry superannuation sector information and an overview of AASB 7 is provided in section 5; the risk standards and processes are presented in section 6 ; followed by the analysis of super fund data in section 7; and finally a conclusion with comments on future research is provided in section 8 .

\section{Research Question}

Our research question is to examine the extent to which the statutory accounts of a sample of industry superannuation funds reported risk in 2007, the year prior to the qualitative and quantitative risk disclosure requirements of the new Australian accounting standard AASB 7 Financial Instruments: Disclosures, issued pre-GFC. ${ }^{5}$ There has been a concern that the new standard AASB 7 will only receive 'lip service' to its requirements. A parallel concern arises from a recently published study on narrative reporting. The ASB report (2009) set out to study how effectively companies communicate and found while the vast majority of companies are technically compliant with regulations, they still fall short of clearly explaining to stakeholders the what and how of sustainability efforts that fail to fulfil their

\footnotetext{
${ }^{3}$ Source:

http://www.companydirectors.com.au/Media/Company+Director/2009/August/Feature+The+evolving + annual+report.htm Accessed 10/2/10

4 Ibid.

5 The effects of the GFC were felt from around August 2008.
} 
policy. The report conclusions were based on a random sample of 50 firms from the 'FTSE 350 and SmallCap'. The investigators noted:

A number of companies resorted to simply providing descriptions of generic risks that could be easily cut-and-pasted into many other FTSE annual reports. ${ }^{6}$

Our study is similar to that of the ASB report for we set out to study how effectively super funds disclose financial risk. The $A A S B 7$ standard applies to entities that are bound to prepare financial reports to enable stakeholders to evaluate the significance of an entity's financial instruments; the nature and extent of risks arises from such instruments; and how an entity manages those risks. The standard affects annual reporting periods beginning on or after 1 January 2007. Many reporting entities with a 30 June balance date have only been obliged to apply the AASB 7 standard to accounts from the 2008 financial year ${ }^{7}$.

This paper uses 2007 statutory financial statements from a sample of 26 of the 74 industry superannuation funds' as its primary data. All are market-linked funds (ie. none are defined-benefit funds). In the sample of industry superannuation funds for this paper, all (except one) have not adopted AASB 7 for their 2007 accounts as their balance date is 30 June $^{8}$. The 2007 data will therefore form the first year of comparative information for use in determining the extent to which the sample funds from the industry superannuation sector comply with the qualitative and quantitative risk disclosure requirements of accounting standard AASB 7.

\section{Literature Review}

Various studies on superannuation industry in Australia have examined the effects of financial disclosure (Ang et. al., 1999; Gallery and Gallery, 2003, 2004, 2008; Clare, 2007). Some studies show the history of recent regulatory changes, guidance for revising accounting standards, and differences across the superannuation industry. For instance one study investigated the value relevance of superannuation disclosures required by AASB 1028 (Ang, et al. 1999). Here the researchers detailed three important findings: disclosed superannuation information is value relevant in the industry super sector, where these items tend to be material; secondly the market weights on the required disclosures are usually higher than those on recognized assets and liabilities; and thirdly, in contrast to the findings in similar US studies, accrued benefits do not have higher explanatory power relative to vested benefits. The outcomes from this type of disclosure investigation are now less relevant in the current climate of extreme market volatility. The concern by all stakeholders of adequate risk disclosure is the context of this study.

More relevant to our current circumstances is the study by Gallery and Gallery (2006). They have argued that financial reporting of superannuation funds is a key governance mechanism, for it is through these reports that stakeholders are informed of a fund's prior investment

\footnotetext{
6 Accounting Standards Board (2009) Review of Narrative Reporting by UK Listed Companies in 2008/2009, 29 October, p.13.

7 The Australian 2008 financial year commenced 1 July 2007 and ended 30 June 2008.

${ }^{8}$ A second paper using 2008 and 2009 super fund financial data will be completed by the authors by the end of 2011, which is when the standard will have been mandatory for two years.
} 
performance, current financial and investment activities, and financial position at year end. The authors analysed the generally available reports of one large industry superannuation fund and concluded that there were three major accounting barriers to transparency. The specific disclosure failures were that the audited financial report was too highly aggregated; the annual report (located on the fund's website) was selective and too simplistic; and it was difficult to reconcile the audited financial report to the website annual report because the former focused on asset classes and the latter focused on investment pools. It should be noted that the Gallery's study considered the selected fund's 2004 accounts, which was before the issue of the new standard, AASB 7 Financial Instruments: Disclosures. Our paper continues to investigate the extent of financial disclosure but to a wider sample of 26 industry super funds.

Clare (2007) provided a summarised history of recent regulatory changes to the superannuation industry starting with the Wallis Committee report, The Financial System Inquiry Final Report 1997. Clare stated the Wallis report was framed around a strategic vision for a proposed regulatory regime, which centred on disclosure of information rather than prescriptive regulator intervention. At the time heavy-handed intervention was not popular with some inquiry members. (Contrast the thinking in 2001 with the taxpayer bail-out of banks in the United States and Europe in 2008.)

Of interest to our research is where Clare cites the Roberto Rocha et. al (2007) study lists and describes superannuation risks including agency risk (where the interests of administrators of a fund diverge from the interests of fund members); systemic risk (a scenario of financial institution failure that threatens consumer confidence) and investment risk. ${ }^{9}$ The Australian Government (via the Accounting Standards Board) is attempting to address investment risk through the issuing of the new accounting standard AASB 7.

Whilst Clare lists and describes a range of risks identified by other researchers and points out how Australian authorities have been forced to respond in the aftermath of corporate collapses such as HIH Insurance and One Tel, he does not address the effectiveness of risk mitigation measures. As a first step in measuring the effectiveness of AASB 7 disclosure requirements, our study seeks to analyse risk disclosures in the 2007 statutory financial statements of the sample superannuation funds, the year prior to the standard being mandatory.

As far as the authors are aware, no other study has been conducted to examine the disclosure of risk on industry superannuation in Australia. The next section will address the methodology for our research.

\footnotetext{
${ }^{9}$ See the Ross Clare (2007) citation of Roberto Rocha, Richard Hinz Joaquin Gutierrez, 'Improving the Regulation and Supervision of Pension Funds: are there lessons from the banking sector?" The World Bank, Washington D.C, 1999, p.6.
} 


\section{Methodology for the Study}

The sample for our study was randomly selected by using Excel's 'Random Sampler' on the list of industry superannuation funds published by Australian Prudential Regulation Authority (APRA). ${ }^{10}$ In 2007, there were 74 industry superannuation funds. However, the detailed data published showed only the largest 58 industry super funds (APRA, 2008). Our sample was 44 industry super funds (market-linked) of which 26 industry super funds responded (59\% response rate). See Table 1 'Sample Frame'.

Table 1. Sample Frame

\begin{tabular}{|c|c|}
\hline Sample Unit & Industry Superannuation funds (78 as per APRA) \\
\hline Respondent & Chief Financial Officer (CFO) \\
\hline Method of contact & Mail (or telephone) \\
\hline Sample size & 44 Funds \\
\hline Response rate & 26 funds responded (response rate is $59 \%$ ) \\
\hline Non-response bias & No response bias was detected as no significant differences were found \\
\hline
\end{tabular}

The chosen industry super funds were contacted by telephone to obtain the names of the functional managers in those organisations. Subsequently, e-mail messages were sent to them requesting full copies of statutory financial statements for the year ended 30 June 2007.

This type of data collection has been criticised mainly for its failure to capture a holistic analysis of the research phenomena and thus seen as less effective for collecting opinions (Yin, 2003). However, this aspect is not central to the objectives of this study.

For industry funds that did not respond by the due date, second and third reminders were sent. Finally a total of 26 responses were received, resulting in a response rate of 59\%. Some funds only sent partial sets of accounts: operating statement, balance sheet and the note on financial instrument disclosure; however this was enough to complete the analysis. Non-response bias tests were undertaken in accordance with those suggested by Oppenheim (1966). No response bias was detected as no significant differences were found.

Our 2007 sample is seen as a preliminary step to the next stage of research for which we will expand the sample number of funds to form comparative data as the AASB 7 Financial Statement Disclosures standard was not mandatory until 2008.

The 2007 data and its compliance to $A A S B 7$ is first analysed via a 'ratings assessment' devised by the researchers, which is shown at Table 2. The construction of the assessment table is based on the qualitative and quantitative criteria required in AASB 7.

${ }^{10}$ APRA, Statistics: Superannuation-Fund-Level-Profiles-and-Performance, December 2008. 
Table 2. Ratings Assessment for AASB 7 Disclosure

\begin{tabular}{|c|c|c|}
\hline & & Weighting \% \\
\hline 1 Qualitative & F inancial ris $\mathrm{k}$ management objectives, polic ies and processes & 1 \\
\hline 2 Qualita tive & C redit $R$ isk & 1 \\
\hline 3 Quantitative & $C$ redit $\mathrm{R}$ isk & 2 \\
\hline 4 Qualita tive & Liquidity $\mathrm{R}$ is $\mathrm{k}$ & 6 \\
\hline 5 Quantitative & Liquidity $\mathrm{R}$ is $\mathrm{k}$ & 6 \\
\hline & Market $\mathrm{R}$ isk & \\
\hline 6 Qualita tive & - interest rates & 14 \\
\hline 7 Quantitative & - interest rates & 14 \\
\hline 8 Qualita tive & - price & 14 \\
\hline 9 Quantitative & - price & 14 \\
\hline 10 Qualitative & - foreign exchange rates & 14 \\
\hline 11 Quantitative & - foreign exchange rates & 14 \\
\hline & & 100 \\
\hline
\end{tabular}

Our 'ratings assessment' methodology is based on the conservative premise that a super fund's narrative on its financial risk management objectives, policies and processes may claim more governance than they deliver, a low weighting was therefore given to this aspect of risk reporting. Further, as industry super funds are only allowed very short term, low value borrowing, 'credit risk' is low and thus allocated a low weighting. Although some super funds invest heavily in non-liquid property assets, the risk in liquidity is low because funds already have to report liquidity ratios to APRA to maintain their Australian Financial Services licence. 'Liquidity risk' is therefore given a low weighting.

During the GFC period it was found that the investments faltered due to higher interest cost, market price crashes and foreign exchange volatility. These risks are therefore equally weighted (noting that AASB 7 does not rank these risks either). An overall rating of at least $50 \%$ would indicate general compliance with risk disclosure.

The 'descriptive statistics' approach (our second method) for data analysis uses univariate analysis (statistics that describe individual variables) and input our data into the software package SPSS, version 17. The data for the determination of frequency was first transferred to an Excel data file and then uploaded to SPSS for analysis. Our paper shows the frequencies found for each variable in the data set: market, liquidity and credit risk. We look at the range of output values and describe the pattern of response to the variable.

The third method applied to our data was 'content analysis'. Since our paper involves examining qualitative risk disclosure in $A A S B$, content analysis has been chosen as an appropriate research method. Content analysis has been defined by a number of researchers (Berelson, 1952; Holsti, 1969; Krippendorff, 1980; Mostyn, 1985; Weber, 1990). It is defined by Krippendorff (1980) as 'a research technique for making replicable and valid inferences from data to their context' (Mostyn 1985; Krippendorff, 1980; Tilt, 2001; Kraal, et al, 2008). 


\section{Industry Superannuation Sector}

The superannuation industry has had a culture of conservatism in the area of disclosure, as it has grown essentially from a base of privately managed funds to the colossus of more than $\$ 1143$ bill in managed funds it is today.

In 1986 under the Hawke-Keating government in Australia, a 3 per cent employer-sponsored superannuation benefit was introduced as part of productivity bargaining for workers under certain wage and salary awards. By after 2002 Superannuation Guarantee had been introduced to $90 \%$ of workers at the level of $9 \% .{ }^{11}$ The profile of the superannuation sector to June 2007 is best summarised by the annual statistics published by APRA. ${ }^{12}$ Tables 3 and 4 show distribution and types of super entities in Australia and highlight the 2007 statistics of industry superannuation funds that are the focus of this paper.

Table 3. Distribution of entities June 2007 by fund type

\begin{tabular}{|l|l|l|l|}
\hline Fund Type & Number of Entities & Number of member accounts ('000) & $\begin{array}{l}\text { Assets } \\
\text { (\$ billion) }\end{array}$ \\
\hline Corporate & 289 & 676 & 69.2 \\
\hline Industry & $\mathbf{7 4}$ & $\mathbf{1 0 , 6 5 4}$ & $\mathbf{1 9 7 . 3}$ \\
\hline Public Sector & 40 & 2,925 & 177.6 \\
\hline Retail & 172 & 15,437 & 369.7 \\
\hline Small & 365,992 & 702 & 286.6 \\
\hline Pooled super trusts & 101 & & \\
\hline Balance of life office funds & & & 42.8 \\
\hline Total & $\mathbf{3 6 6 , 6 6 8}$ & $\mathbf{3 0 3 9 4}$ & $\mathbf{1 1 4 3 . 2}$ \\
\hline
\end{tabular}

Source: Australian Prudential Regulation Authority, Statistics: Annual Superannuation Bulletin June 2007, p.27.

\footnotetext{
11 Australian Prudential Regulation Authority, Statistics: Annual Superannuation Bulletin June 2007 (Issued 26 March 2008).

12 Ibid.
} 
Table 4. Superannuation entities June 2007 by regulatory classification

\begin{tabular}{|l|l|l|l|}
\hline Fund by Regulatory Classification & Number of Entities & $\begin{array}{l}\text { Assets } \\
\mathbf{( \$ ~ b i l l i o n ) ~}\end{array}$ & Average account balance (\$000) \\
\hline - APRA regulated & & & \\
\hline Public offer super funds & 225 (Industry: 42) & 544.7 & 27 \\
\hline Non-public offer super funds & 308 (Industry: 32) & 153.5 & 54.1 \\
\hline Approved deposit funds & 155 & 0.3 & 30.9 \\
\hline Eligible rollover funds & 17 & 5.7 & 1.1 \\
\hline Small APRA funds & 6,017 & 3.7 & 405.1 \\
\hline Total & $\mathbf{6 , 7 2 2}$ & $\mathbf{7 0 8}$ & $\mathbf{2 5}$ \\
\hline & & & \\
\hline -ATO regulated & & & \\
\hline Self-managed super funds & 359,825 & 282.7 & 408.5 \\
\hline & & & \\
\hline -Other & & & \\
\hline Exempt schemes & 20 & 109.7 & 76.9 \\
\hline Pooled superannuation trusts & 101 & 83.7 & \\
\hline Balance of life office funds & & 42.8 & \\
\hline Total & $\mathbf{3 6 6 , 6 6 8}$ & $\mathbf{1 , 1 4 3 . 2}$ & \\
\hline
\end{tabular}

Source: Australian Prudential Regulation Authority, Statistics: Annual Superannuation Bulletin June 2007, p.27.

As can be seen from the preceding Tables 3 and 4, the industry superannuation fund sector shows significant figures for 2007 with regard to number of members and value of assets held. Industry funds are spread between public offer and non-public offer funds. For the typical member with an account balance of between $\$ 27,000$ and $\$ 54,000$ the unforeseen global economic downturn in financial market returns since mid-2008 are of ongoing concern.

Industry superannuation funds have been selected because they invest and manage the retirement savings for over 10,000,000 Australians. As can be seen from Table 5 and Graph 1, the industry superannuation fund sector has the second largest number of members, with a significant number of members at the age where they are eligible to draw on their benefits. As many Australians approach retirement, much is at stake in their superannuation investment. This concern can be evidenced by actions such as industry super fund administrators requesting Bernie Fraser (ex- Australian Reserve Bank Governor) to provide calming words to investors in a televised national broadcast and ongoing advertisements. ${ }^{13}$

\footnotetext{
13 Bernie Fraser spoke about the need for investors not to panic and to view superannuation as a long tern investment. Televised national broadcast, 6pm, 14 October 2008. Advertisements have been screened on television in 2009.
} 


\section{Macrothink}

Table 5. Age Segmentation of member accounts by fund type ('000s)

\begin{tabular}{|l|l|l|l|l|l|l|}
\hline Fund Type & $\underline{\mathbf{3 5 y r s}}$ & $\underline{\mathbf{3 5 - 4 5} \mathbf{y r s}}$ & $\underline{\mathbf{5 0 - 5 9} \mathbf{y r s}}$ & $\underline{\mathbf{6 0 - 6 5} \mathbf{y r s}}$ & $\underline{\mathbf{3 6 5} \mathbf{y r s}}$ & $\underline{\text { Total }}$ \\
\hline Corporate & 249 & 278 & 112 & 24 & 14 & 676 \\
\hline Industry & $\mathbf{5 , 4 8 8}$ & $\mathbf{3 , 3 5 7}$ & $\mathbf{1 , 3 6 2}$ & $\mathbf{3 4 2}$ & $\mathbf{1 0 5}$ & $\mathbf{1 0 , 6 5 4}$ \\
\hline $\begin{array}{l}\text { Public } \\
\text { sector }\end{array}$ & 740 & 1,126 & 657 & 192 & 210 & 2,925 \\
\hline Retail & 6,284 & 5,649 & 2,320 & 737 & 447 & 15,437 \\
\hline & & & & & & \\
\hline Total & $\mathbf{1 2 , 7 6 1}$ & $\mathbf{1 0 , 4 1 0}$ & $\mathbf{4 , 4 5 1}$ & $\mathbf{1 , 2 9 5}$ & $\mathbf{7 7 6}$ & $\mathbf{2 9 , 6 9 3}$ \\
\hline
\end{tabular}

Source: Australian Prudential Regulation Authority, Statistics: Annual Superannuation Bulletin June 2007, p.31.

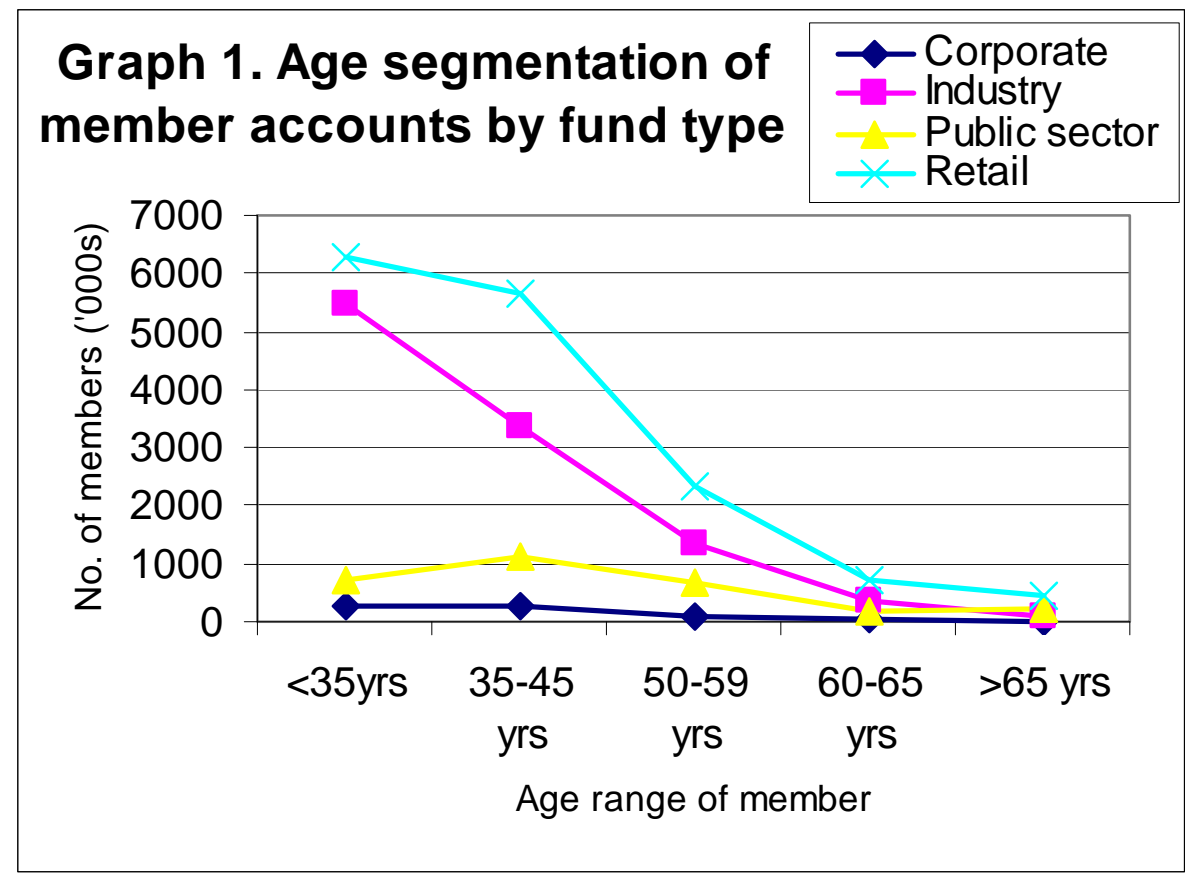

Graph 1.

\subsection{Disclosure Requirement of AASB 7}

The accounting standard AASB 7 Financial Instruments: Disclosures was introduced to require 'reporting entities' to assist their stakeholders in evaluating the significance of financial instruments in relation to an entity's position and performance. ${ }^{14}$ The standard is also aimed at assisting stakeholders determine the nature and extent of risks arising from financial instruments. ${ }^{15}$ The standard's disclosure requirements are broad and cover objectives, policies and procedures (incorporating methodologies) for managing financial risk.

14 A 'reporting entity' is required to prepare financial reports in accordance with Part 2M.3 of the Corporations Act.

15 AASB7, para 1. 
The predecessor to the AASB 7 standard was AASB 132 Financial Instruments: Disclosure and Presentation, which required only a statement on the risks of a fund including risk management policies. $A A S B 7$ supersedes the disclosure requirements of $A A S B 132$ but the presentation requirements of the latter remain unchanged.

An example of the additional disclosure requirements of $A A S B \quad 7$ is that the accounting polices used in preparing the accounts must be stated. Importantly, types of hedge accounting must be described, including fair value hedges, cash flow hedges and hedges of net investments in foreign operations. ${ }^{16}$ Disclosure required can extend to types of investments held within the fund; the role of the investment manager; how compliance for the range of investment risk is monitored by the investment manager; and the range of risks exposed and how they arise. The disclosure is based on information likely to be provided internally to key management personnel including the Board. Involvement of fund clients may be required to complete some disclosures. Generally, in a comparison between AASB 132 and the new $A A S B$ 7, the latter is far more prescriptive on disclosure details.

This paper will only focus on disclosures prescribed by AASB 7 paragraphs 31 to 42 in the section that is headed 'Nature and extent of risks arising from financial instruments'. The reason for restricting the paper to this aspect is because the global economic downturn has forced many investors to address their lack of understanding of the inherent risks attached to their investment portfolios, and so our study will help determine the assistance provided by AASB 7.

\subsection{Nature and Extent of Risks Arising from Financial Instruments}

With regard to risk generally, superannuation funds are increasingly turning to forensic risk management tools in an effort to capture their absolute exposure in a range of portfolios. According to JP Morgan Worldwide Securities Services, the global financial crisis has led to 'a seismic change in super funds, with funds seeking a better understanding of risk investment exposure in portfolios holding public, private and alternative investments.' The report stated that 'driving this seismic change in funds' requirements is the increased need that funds have to build a greater understanding of their risk of investment exposure, as well as exposure to supplier risk associated with using a range of financial services'. ${ }^{17}$

The AASB 7 standard requires additional information across the categories of 'qualitative' and 'quantitative' disclosure for range of risks arising from financial instruments. Typical types of risk can include, but are not limited to: market, liquidity and credit risks. The sections below detail the risk categories with suggestions about commentary on the more common risks. The key objective of the disclosure is that additional financial information is available to competitors, analysts, investment advisors, potential members under 'Choice of Fund' as required by the afore-mentioned simpler super legislation.

\footnotetext{
${ }^{16}$ AASB7, paras.21-24.

${ }^{17}$ Comments by Jane Perry, chief executive, Worldwide Securities Services Australia at the 'Conference of Major Superannuation Funds', as reported by Amal Awad in Super Review, 24 March 2009.
} 


\subsubsection{Qualitative disclosure}

(a) Market Risk

The reporting entity must provide a narrative on three sub-types of market risk including currency, interest rate and price risk. ${ }^{18}$ For instance concentrations of currency risk and information on how it is monitored and managed can be detailed. Comments could be provided on interest risk and how it is monitored and managed. Any number of 'other price' risks that affect profit and net assets can be provided, and for many price risk on equities are of concern; however there could be other weak points considered such as commodity price risk, given the 2008 downturn in demand from China.

(b) Liquidity

For liquidity risk, an explanation of exposure to risk and how it arises could be given. ${ }^{19}$ For instance, many superannuation fund members made investment switches in 2008 (from shares to cash) which impacted the liquidity position of their superannuation fund.

(c) Credit

For credit risk, a description of collateral held as security is required. ${ }^{20}$ For instance, a description of how credit risk associated with an entity's service organisations (bankers, custodian or fund managers) is monitored could be detailed, including information on collateral held as security for financial assets.

\subsubsection{Quantitative disclosure}

(a). Market Risk

Integral to the presentation of market risks is the requirement for a sensitivity analysis for each type of risk (currency, interest rate and price) showing how profits and equity might be affected by fluctuations: for instance rates. Methods and assumptions used must be disclosed as well as changes on such from the previous reporting period. If some part of the analysis is unrepresentative, then that fact must be clearly disclosed. ${ }^{21}$

For the presentation of currency risk data, guidance might be drawn from the AASB 132 example of assets and liabilities values being affected by the risk of different currencies.

\footnotetext{
18 The types of market risk: currency, interest and price risk are defined in Appendix A, AASB7.

19 AASB7, para. 39(b).

20 AASB7, para. 36(b).

21 AASB7, paras. 40-42.
} 


\section{Macrothink}

Here a fund can prepare a sensitivity analysis of the currency movements against the Australian dollar (or other main currency) and its impact on profits and/or members equity.

For interest rate risk, a summary of fixed and variable interest could be prepared. The sensitivity analysis might show interest rate movements based on a volatility factor as at the balance sheet date.

The sensitivity analysis for 'other price' risk might show movements of listed equities in the fund financials. If unlisted equities comprise a significant proportion of the portfolio, further information (for example, market valuations) may be required to derive the movement factor.

As an alternative option, an entity utilise its in-house sensitivity analysis. Essentially the aim is to quantify the effect on profit and on members' funds for a reasonable change in that risk variable.

(b) Liquidity

The AASB 7 requirement for liquidity risk is to present a maturity analysis for financial liabilities that shows remaining contractual maturities. ${ }^{22}$ For instance any net settled derivatives, which have a negative fair value at the balance sheet date, could be included in the liquidity analysis at contract amounts. When a third-party has a choice of when an amount is paid, the liability is included on the basis of the earliest date on which the fund might be required to repay.

(c) Credit

The AASB 7 standard on quantitative credit disclosure, inter alia, requires details that best represent an entity's maximum exposure to credit risk at the reporting date (without taking account of any collateral held or other credit enhancements). ${ }^{23}$ For instance, disclosure could comprise financial assets including debt securities; or cash and other receivables showing balance exposure as at period end, split by asset class. Presentation of data could show concentrations of risk.

An organisation's management practices are directed at achieving its aims in an efficient and effective manner, including the identifications of management of those risks that prevent it from achieving their aims. Risk management approaches have some common features, such as:

- Identifying objectives related to a project, activity or program,

- $\quad$ Pinpointing the risks to achieving these objectives, and

- $\quad$ Implementing ways of dealing with these risks.

\footnotetext{
${ }^{22}$ AASB7, para. 39.

${ }^{23}$ AASB7, para. 36.
} 
Risk management is now widely accepted as a key element of sound governance practice in large and complex organisations and as a valuable tool for integrating all aspects of management planning and decision making. An executive at a 2009 superannuation conference stated that 'it will become increasingly essential to have the correct data on superannuation fund members in order to manage risk'. ${ }^{24}$ At the same conference Howard Rosario, chief executive, Westscheme Superannuation Fund, stated that it was important to discharge the trustee's fiduciary duty, manage risk and communicate with members. Rosario stressed the significance of maintaining proper data in order to manage risk, pointing to the possibility of negatively impacting asset allocations with bad data. 'It will drain liquidity and strain administrative resources if corrupt data makes changes [for members] more difficult,' Rosario said.

APRA industry investigations have identified two major tendencies, 'deliberate indifference and conscious avoidance and problems found included financial losses, critical data errors, incorrectly paid benefits and a failure to follow up data errors systematically.' Recent liquidity updates showed limited trustee ability to extract useful information at short notice. APRA's view is that internal audit focus should be improved and that a greater alignment with risk management was necessary. ${ }^{25}$ The accounting standard AASB 7 formalises the requirement for reporting entities to disclose information about risks arising from financial instruments.

\section{Risk Standards and Processes}

Risk management has become a key focus in the public and private sector since the release of the first Australian/New Zealand Standard for Risk Management (currently AS/NZS4360:2004) and the related standards such as the Compliance Programs (AS 3806:1998). The Risk Management standard provides a generic framework within which organisations can implement risk management. The objective of the Risk Management process is to identify all unacceptably high-level risks and put in place processes and structures to deal with them. Lower level risks are also considered but priority is given to significant risks. The stages of the process are Risk Identification, Risk Analysis \& Evaluation, Monitoring \& Control and Continuous Improvement. These stages are outlined by the diagram below followed by some detail on each process stage:

\footnotetext{
${ }^{24}$ Comments by Ramani Venkatramani, general manager, specialised institutions division, APRA for the 'Conference of Major Superannuation Funds' as reported by Amal Awad in Super Review 'Data integrity tied to risk management'24 March 2009.

${ }^{25}$ Ibid. Further comments by Venkatramani.
} 


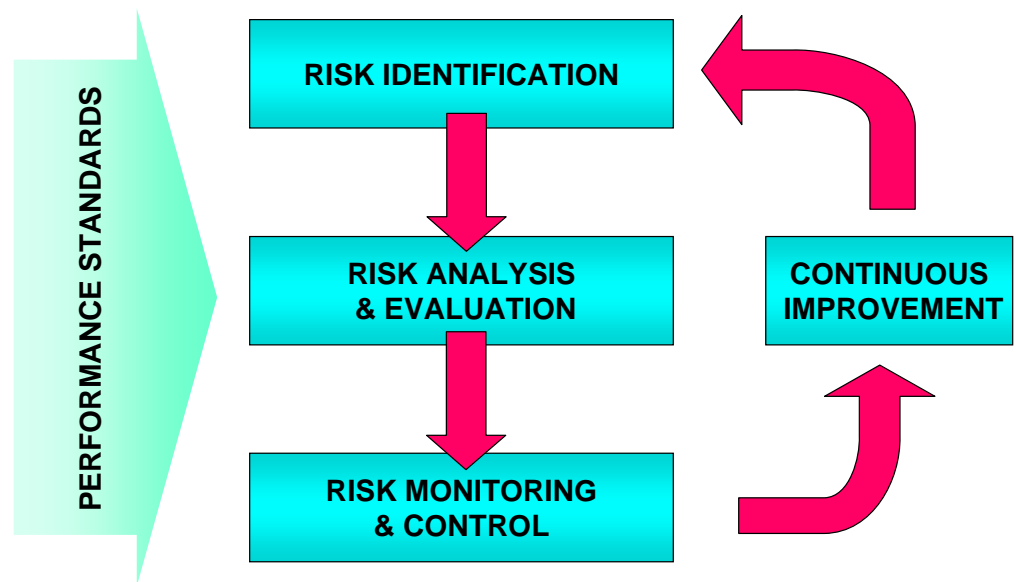

\subsection{Risk Identification and Analysis}

Risks (such as market, liquidity and credit) can be expressed as risk scenarios and formally recorded in a document such as a 'risk scenario management sheet'. The existing risk controls are determined and analysed in terms of consequence and the likelihood in the context of these controls. A reasonable analysis should consider the range of consequences and probability identified in the risk matrix. The levels of risk are compared against pre-established acceptance criteria and ranked into extreme, high, moderate and low risk. For entities subject to AASB 7 for example, it is required that market risk are subject to a sensitivity analysis for each type of risk (currency, interest rate and price).

\subsection{Risk Categories}

Generally risk categories are chosen to reflect the diversity and complexity of an organisation's operations. However, in the case of the AASB 7 standard, the risk categories of market, liquidity and interest are prescribed. Before the global economic downturn many large retail and industry super funds seemed more concerned with including a reasonable level of environmental products in their investment suite. Reputational damage to the superannuation sector due to dramatic loss of investment value has caught the industry by surprise.

\section{Analysis of the Sample Superannuation Funds' 30 June 2007 data}

\subsection{Ratings Analysis Results}

Data from the 30 June 2007 statutory accounts of 26 sample industry superannuation funds (those which responded to our emails) have been depicted in Graph 2 'Ratings for AASB 7 Disclosure of 26 Industry Super Funds, 30 June 2007 data' using the ratings methodology described in section 4 (and shown at Table 2). Three funds gained a rating of more than 50 per cent, which indicates a general level of disclosure to their stakeholders; all other funds in the sample follow the trend of falling below this level. The disclosure benchmark set by this quorum of funds is therefore rather low, which can be explained by the fact that 25 funds did not have to comply with AASB 7 until the 2008 financial year. It is important to note that only one fund (No. 9) was required to comply with AASB 7 in the 2007 financial year (but with a low rating of $39 \%$ ). Interestingly, this fund's narrative about its price risk on equities declared 
that policies and procedures were in place to mitigate the fund's exposure to market risk. After the onset of the GFC, all industry superannuation funds experienced four successive quarters of negative returns, except in the $100 \%$ cash option. ${ }^{26}$
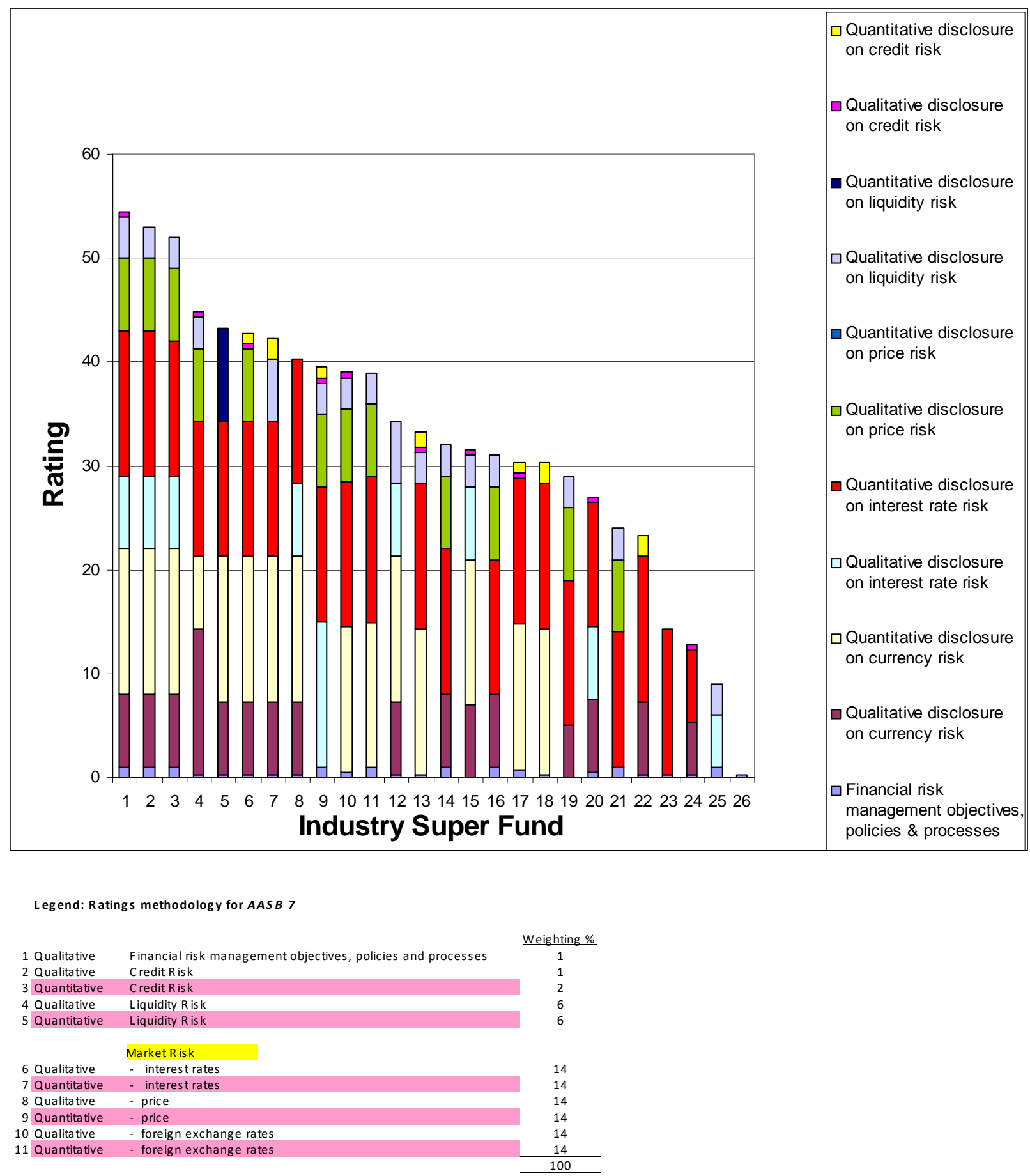

Graph 2. Ratings for AASB 7 Disclosure of 26 Industry Super Funds, 30/6/07 data.

\footnotetext{
${ }^{26}$ See the Super Ratings media release about industry superannuation fund results, 28 October 2008 http://www.superratings.com.au/media/mediareleases/20081027
} 


\subsection{Descriptive Statistics Results}

The frequencies of qualitative and quantitative disclosure on (a) market risk (b) liquidity risk and (c) credit risk was analysed using the SPSS statistical package. Table 6 'Frequencies of qualitative and quantitative risk disclosure of 26 industry super funds using 30 June 2007 data' shows the SPSS results at the pre-determined percentage breaks of: $0 \%, 2 \%, 3 \%, 5 \%$, $7 \%, 8 \%, 9 \%$, and $100 \%$.

Graph 3 depicts quantitative data from Table 6. It shows liquidity and credit risk with the highest rate of non-disclosure, which is due to the liquidity ratios (post-Commercial Nominees) already being a mandatory reporting item to APRA, whilst credit risk is low because of strict limits on borrowing by industry super funds. The absence of 2007 disclosure on 'other price risk' should be of concern because of the subsequent GFC. By contrast almost $50 \%$ of the funds had full disclosure on interest and currency risks.

Graph 4 depicts qualitative data from Table 6. It shows between 39\%-62\% of funds had no narrative explaining any of the risks. In line with the quantitative trend, only $4 \%$ of the funds provided a full narrative on interest and currency risks. For both quantitative and qualitative disclosures it should be reiterated that in 2007 there was no mandatory requirement for 25 of the 26 super funds to comply with $A A S B$ 7. In this initial paper we will not explore in detail the reasons for the unequal disclosure on each of the variables. It will be more appropriate to address this outcome when we produce the next paper using 2008 and 2009 data.

Table 6. Frequencies of Qualitative and Qualitative Risk Disclosure of 26 Industry Super Funds using 30 June 2007 data $^{27}$

\begin{tabular}{|c|c|c|c|c|c|c|c|c|c|c|c|c|c|c|c|c|}
\hline Varidble & & & & & Disclosure Freq & & & & & & & & & & & \\
\hline & No. of Funds & $\%$ & No. of Funds & $\%$ & No. of Funds & $\%$ & No. of Funds & $\%$ & No. of Funds & $\%$ & No of Funds & & of Funds & $\%$ & No. of Funds & $\%$ \\
\hline Market Risk & No disc. & & $2 \%$ disc. & & $3 \%$ disc. & & $5 \%$ disc. & & $7 \%$ disc. & & $8 \%$ disc. & & 9\%disc. & & Full Disc. & \\
\hline Qmeny RiskQd. & 10 & 39 & 0 & 0 & 0 & 0 & 15 & 57.7 & 0 & 0 & 0 & 0 & 0 & 0 & 1 & 3.8 \\
\hline Ameny/RskQunt & 11 & 42 & 0 & 0 & 0 & 0 & 1 & 3.8 & 0 & 0 & 0 & 0 & 0 & 0 & 14 & 54 \\
\hline InterestRiskqu. & 17 & 65 & 0 & 0 & 0 & 0 & 8 & 30.8 & 0 & 0 & 0 & 0 & 0 & 0 & 1 & 3.8 \\
\hline IrterestPskQuat. & 3 & 12 & 0 & 0 & 0 & 0 & 0 & & 3 & 11.5 & 8 & 31 & 0 & 0 & 12 & 46 \\
\hline Other PiœeRskQua. & 14 & 54 & 0 & 0 & 0 & 0 & 12 & 462 & 0 & 0 & 0 & 0 & 0 & 0 & 0 & 0 \\
\hline Other PiceRskQuat. & 26 & 100 & 0 & 0 & 0 & 0 & 0 & 0 & 0 & 0 & 0 & 0 & 0 & 0 & 0 & 0 \\
\hline LiqidtyRiskqu. & 10 & 39 & 0 & 0 & 0 & 0 & 14 & 53.8 & 0 & 0 & 0 & 0 & 0 & 0 & 2 & 7.7 \\
\hline LiqidtyPiskQat. & 25 & 96 & 0 & 0 & 0 & 0 & 0 & & 0 & 0 & 0 & 0 & 0 & 0 & 1 & 3.8 \\
\hline CredtRiskQal. & 16 & 62 & 0 & 0 & 0 & 0 & 10 & 38.5 & 0 & 0 & 0 & 0 & 0 & 0 & 0 & 0 \\
\hline CredtRiskQant & 19 & 73 & 0 & 0 & 0 & 0 & 2 & 7.7 & 0 & 0 & 1 & 3.8 & 0 & 0 & 4 & 15 \\
\hline
\end{tabular}

\footnotetext{
${ }^{27}$ Table 6 for example shows for 'currency risk qualitative disclosure' 10 funds with no disclosure, which was $39 \%$ of the sample $(10 / 26 \times 100=39 \%)$.
} 


\section{Macrothink}

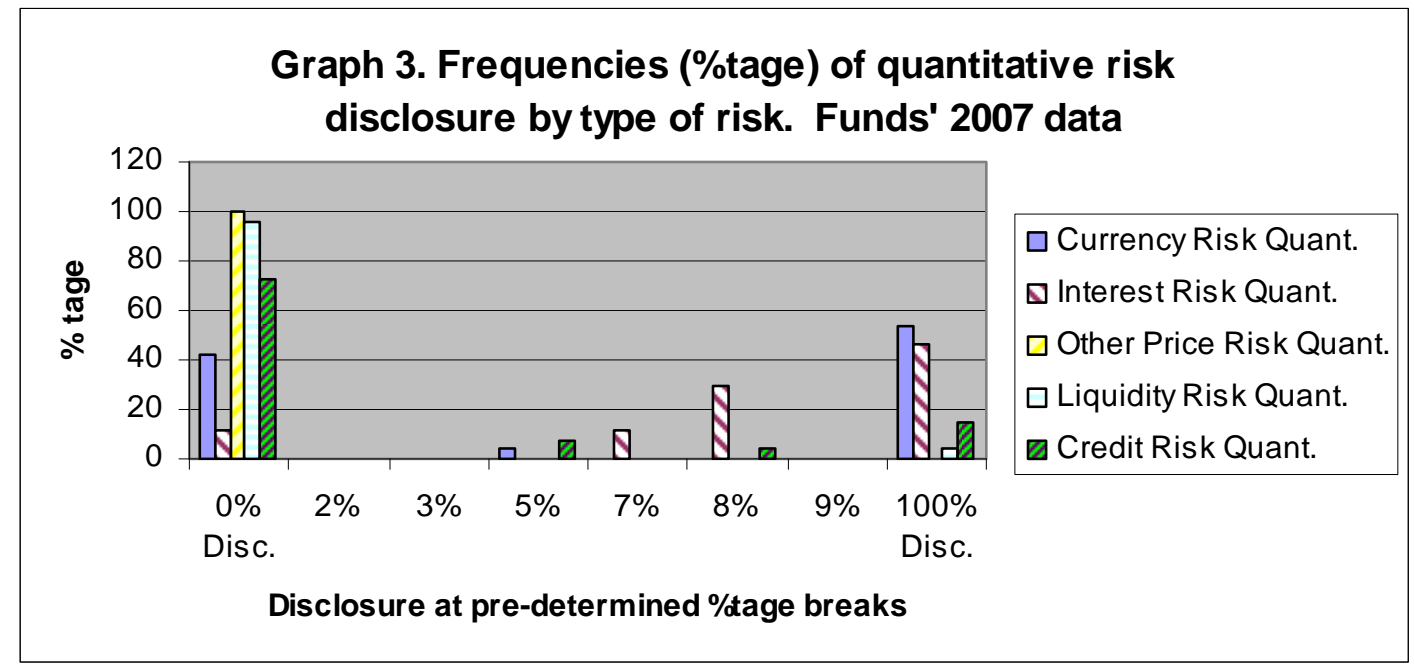

Graph 3.

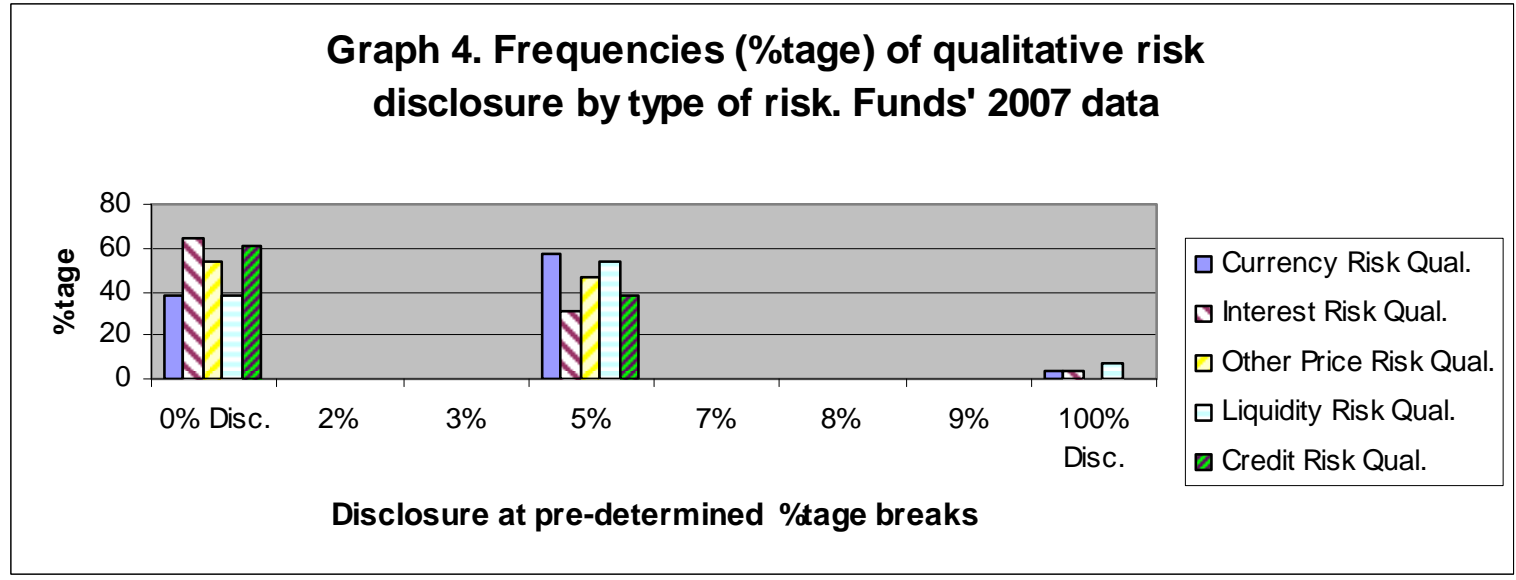

Graph 4.

\subsection{Content Analysis Results}

The statutory financial statements of 26 sampled super funds were analysed using content analysis. In our analysis of sample financial reports, it was revealed that in general, the length of the descriptions about risk varied from a few short sentences, to a one A4 page containing 20 sentences. The mean number of sentences was 2.36. The standard deviation, an indicator of variability from the mean, was 2.16 sentences. Most 'risk' information contained a general statement of policy followed by a series of specific aims or objectives. Some of the objectives were described extensively. The following quotation from a financial statement of an industry super fund typifies the general statements made regarding compliance with AASB 7: 


\section{Macrothink}

The Fund is exposed to a variety of financial risks as a result of its activities. These risks include market risk (including currency risk, fair value interest rate risk and price risk), credit risk, liquidity risk and cash flow interest rate risk. The Fund's risk management and investment policies, approved by the Trustee, seek to minimise the potential adverse effects of these risks on the Fund's financial performance. Consistent with regulatory requirements, the Trustee has the function of overseeing the establishment and maintenance of risk-based systems and controls for the Fund. The Trustee has developed, implemented and maintains a Risk Management Strategy (RMS) and a Risk Management Plan (RMP).

The fund has risk management plan and identified risk categories including investment (market and counter party); financial risk and liquidity; general outsourcing including agency; governance and decision making; compliance and changes in RSE licensing law; fraud and theft; specified outstanding risks; and insurance and external. ${ }^{28}$

Table 7 'Qualitative Risk Disclosure' shows the categories of variables investigated using content analysis. The first column indicates the variable used in the sample. The second and third columns respectively show the funds' disclosure information. The fourth column shows the frequency of each variable's inclusion in the financial report. The fifth column reports frequency of sentences as a percentage. Sixth and seventh columns reflect the mean of sentences dedicated to each variable and the standard deviation of each variable respectively. Graph 5 'Content Analysis of Risk Disclosure' shows the graphical representation of mean and standard deviation of sentences on qualitative risk disclosures of the sample superannuation funds.

28 The name of the industry super fund has been deleted to preserve anonymity. 


\section{Macrothink}

Asian Journal of Finance \& Accounting ISSN 1946-052X 2012, Vol. 4, No. 1

Table 7. Qualitative Risk Disclosure: content analysis (by pre-determined category and number of words) of 26 Industry Super Funds using 30 June 2007 data

\begin{tabular}{|c|c|c|c|c|c|c|}
\hline $\begin{array}{l}\text { Pre-determined } \\
\text { category of } \\
\text { classification of each } \\
\text { sentence in financial } \\
\text { report }\end{array}$ & $\begin{array}{l}\text { Number of } \\
\text { funds not } \\
\text { disclosed }\end{array}$ & $\begin{array}{l}\text { Number of } \\
\text { funds } \\
\text { disclosed }\end{array}$ & $\begin{array}{l}\text { Frequency } \\
\text { (n) }\end{array}$ & $\begin{array}{l}\text { Frequency } \\
\text { as a } \\
\text { percentage }\end{array}$ & $\begin{array}{l}\text { Mean } \\
\text { sentences }\end{array}$ & $\begin{array}{l}\text { Standard } \\
\text { deviation }\end{array}$ \\
\hline $\begin{array}{l}\text { General policy } \\
\text { statement }\end{array}$ & 0 & 26 & 40 & 100 & 3.17 & 1.94 \\
\hline Stated objectives & & & 34 & 85 & 8.37 & 7.11 \\
\hline Stated policies & & & 15 & 37 & 1.45 & 3.00 \\
\hline Other sentences & & & 13 & 32 & 1.22 & 3.59 \\
\hline \multicolumn{7}{|l|}{ Market risk: } \\
\hline currency risk & 10 & 16 & 22 & 54 & 0.85 & 0.98 \\
\hline interest rate risk & & & 14 & 35 & 0.79 & 1.06 \\
\hline other price' risk & & & 3 & 8 & 0.15 & 0.33 \\
\hline Liquidity risk & 10 & 16 & 23 & 58 & 3.81 & 0.47 \\
\hline Credit risk & 16 & 10 & 18 & 45 & 1.46 & 0.97 \\
\hline
\end{tabular}




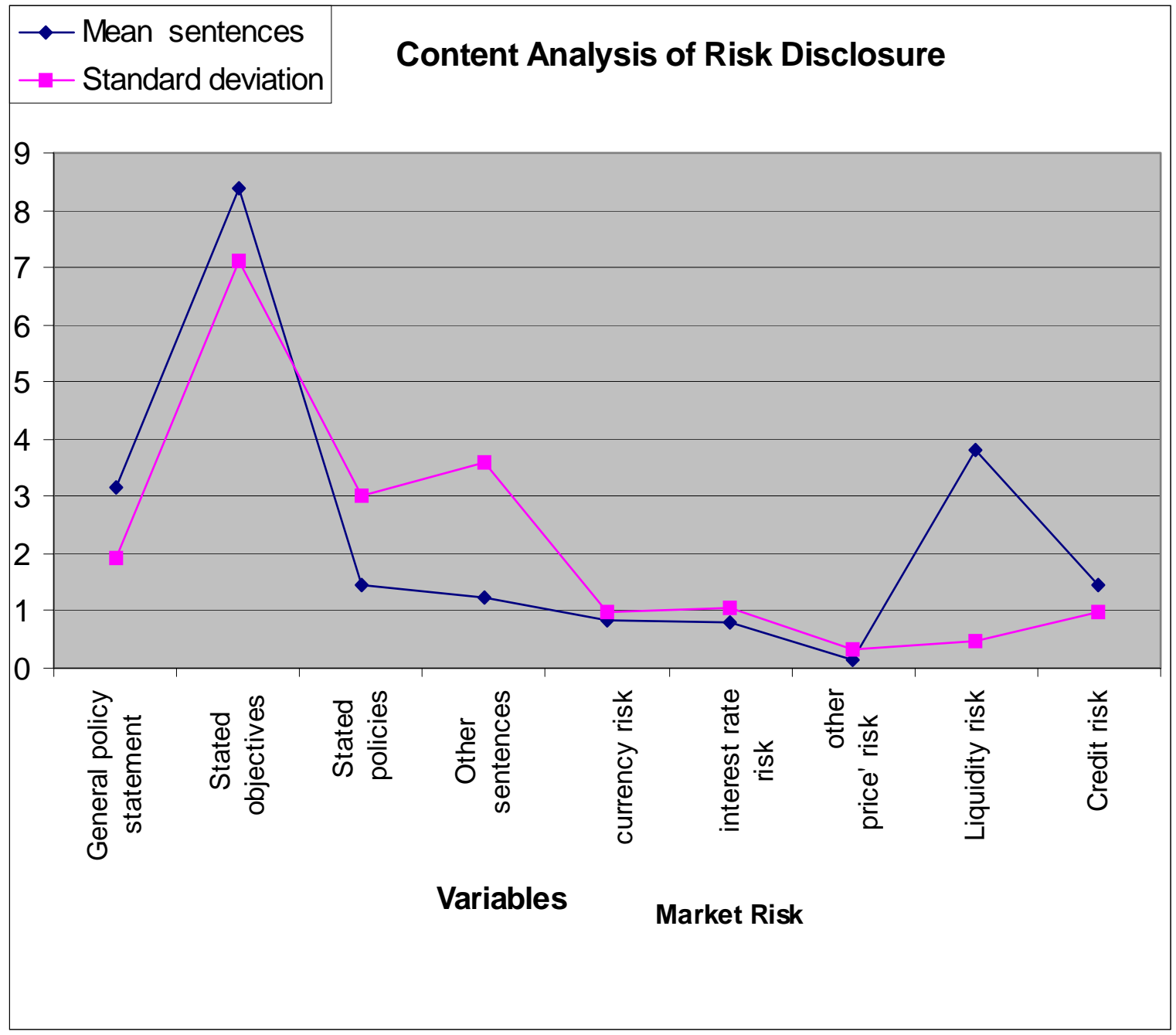

Graph 5. Content Analysis of Risk Disclosure - mean and standard deviation

Graph 5 'content analysis of risk disclosure' show that for 85 per cent of funds in the sample, the greatest proportion of sentences in a financial report are in 'Stated Objectives'. This indicates that the sample super funds are disclosing objectives and policies with some clarity in their financial statements. Notably, however, narrative on market risk (currency, interest rate and other price risks) appeared in a mere 13 of the financial statements and where it did appear, there were only a few sentences dedicated. For each of currency, interest rate and other price risks, less than one sentence was dedicated. Liquidity risk was disclosed by 16 industry super funds and the mean sentences were 3.81 and credit risk was disclosed by 10 funds with a mean number of sentences of 1.46 .

Many studies on financial disclosure tend to measure one or a combination of words, sentences or pages. Number of pages as a yardstick of disclosure is often said to be problematic due to differences arising from font size, margins, graphics etc, while the number of words causes difficulties due to styles of writing: those verbose compared to those concise 
(Hackston and Milne, 1996; Tilt, 2001). Our analysis used pre-determined categories of information to overcome the issues. The overall trend is that market risk is poorly articulated.

\section{Conclusions and future research}

This exploratory paper has examined the extent to which the statutory accounts of a sample of industry superannuation funds reported risk in 2007, the year prior to the qualitative and quantitative risk disclosure requirements of the new Australian accounting standard AASB 7 Financial Instruments: Disclosures. This subject has received relatively little attention in the literature as it relates to a new accounting standard.

The data from the 2007 statutory financial accounts of the sampled 26 industry superannuation funds will be enlarged in the post-exploratory stage to form the first year of comparative information for a longitudinal study to cover the subsequent years 2008-2009, which will use the same sample of superannuation funds.

Three methodologies were applied to the sample of published financial data. The first method was a 'ratings assessment' showing that 23 of the 26 funds had a rating of less than 50 per cent. The trend of low level of risk disclosure can be explained by the fact that all except one fund did not have to comply with $A A S B 7$ until the 2008 financial year. It is also interesting to note that no superannuation fund provided sensitivity information on 'price risk' despite the fact that subtle changes with this risk may affect profit and net assets of superannuation funds.

The second interrogation of disclosure data used 'descriptive statistics' revealing a trend of low levels of risk disclosure. On the basis of this result, we might infer that super funds are likely to place a higher emphasis on 'objectives' and 'policy' descriptions rather than discussion on associated risk (particularly market risk). The final analysis was by 'content analysis' of descriptions of risk mitigation, which showed that for 85 per cent of funds in the sample, the greatest proportion of sentences in a financial report is in 'Stated Objectives'. This indicates that the sample super funds are disclosing objectives and policies with some clarity in their financial statements, whilst the trend for narratives on market risk (currency, interest rate and other price risks) was minimal or low.

The findings, however, must be interpreted with caution as it is only an exploratory study to test out our triangulation of methodologies. A second limitation was that the data was collected using email requests for published financial data. Consistent with other studies employing this method, it is difficult to capture a comprehensive, holistic and contextual portrayal of the empirical phenomena studied without case study or interview. These approaches are important for a topic of this nature. Case studies or interview methods have greater potential to reveal more pragmatic information (Yin, 2003). Hence, as mentioned in the paper, a questionnaire survey followed by ten interviews will be conducted in future research with selected industry superannuation fund managers. The objective will be to study industry superfund manager's opinions and suggestions for the improvement of reporting entity disclosure on $A A S B 7$. 
The third limitation of the study is its focus only on industry super funds. The disclosure of risk is a requirement of many other industry sectors, but any extrapolation the results reported in this paper to other sectors should be done with caution. Lastly, it should be acknowledged that the choice of a risk disclosure is likely to be influenced by a considerable number of factors. These include inter alia fund size, technology and complexity etc. As mentioned below, further research is needed to shed useful light on these issues. This exploratory study has succeeded to some extent determining the appropriate methodology for measuring risk disclosure by industry super funds during 2007.

It is envisaged that data from our current and future research will provide a more informed basis for the future refining of risk disclosure by superannuation funds (and other entities) in Australia and thus be invaluable for all stakeholders including government policy makers, accounting standard researchers, industry regulators and the wider community.

\section{References}

Accounting Standards Board. (2009). Review of Narrative Reporting by UK Listed $\begin{array}{llll}\text { Companies in 2008/2009, } 29 & \text { October. Source: }\end{array}$ http://www.frc.org.uk/ASB/press/pub2148.html. Accessed 1/02/10

Ang, Nicole, Gallery, G., \& Sidhu, B.K. (1999). The value relevance of superannuation disclosures by Australian Listed firms sponsoring defined benefit plans. Accounting and Finance, 39 pp. 205-228. http://dx.doi.org/10.1111/1467-629X.00024

Australian Prudential Regulation Authority. (2007). Statistics: Annual Superannuation Bulletin June 2007, issued 26 March 2008.

Australian Prudential Regulation Authority. (2008). Statistics: Superannuation-Fund-Level-Profiles-and-Performance, December 2008.

Berelson, B. (1952). Content Analysis in Communication Research, Glencoe, Ill: Free Press.

Collet, P., Godfrey, J., \& Hrasky, S. (1998). Standard-Setting in Australia: Implications of Recent Radical Reform Proposals. Australian Accounting Review, Vol.8, No.2, Nov, pp 9- 17. http://dx.doi.org/10.1111/j.1835-2561.1998.tb00084.x

Clare, R. (2007). What are the real risks in superannuation funds an how well are these addressed by regulatory requirements? Conference paper, UNSW 16th Annual Colloquium of Superannuation Researchers July 2007.

Gallery, G., \& Gallery, N. (2003). Inadequacies and inconsistencies in superannuation fund level financial disclosure: the need for a principles-based approach. The Australian Economic Review, 36(1) :89-97. http://dx.doi.org/10.1111/1467-8462.00269

Gallery, G., \& Gallery, N. (2004). Applying conceptual framework principles to Superannuation fund accounting. Abacus, Vol.40, No.1.pp.117-131. http://dx.doi.org/10.1111/j.1467-6281.2004.00146.x 


\section{Macrothink}

Gerry Gallery, \& Natalie Gallery. (2006). Accounting Impediments to better Superannuation Fund Governance. Accounting Accountability \& Performance, Vol.2, No.2.

Gallery, G., \& Gallery, N. (2008). Superannuation financial reporting. National Accountant, 24 (1):70-71, National Institute of Accountants.

Hackston, D., \& Milne, M. J. (1996). Some Determinants of Social and Environmental Disclosures in New Zealand Companies. Accounting, Auditing \& Accountability Journal, Vol.9, No.1, pp. 77-108. http://dx.doi.org/10.1108/09513579610109987

Holsti, O. R. (1969). Content Analysis for the Social Sciences and Humanities. Reading, MA: Addison-Wesley.

Kraal, D., Yapa, P.W.S, \& Harvey, D. (2008). The Impact of Australia's Fringe Benefits Tax for Cars on Petrol Consumption and Greenhouse Emissions. Australian Tax Forum, vol. 23, No.2, pp.191-216.

Krippendorff, K. (1980). Content Analysis: An Introduction to Its Methodology, Newbury Park, CA: Sage.

Mostyn, B. (1985). The Content Analysis of Qualitative Research Data: A Dynamic Approach, in Brenner, Michael, Brown, Jennifer and Canter, David (Eds), The Research Interview, Uses and Approaches, London: Academic Press, pp. 115-146.

Oppenheim, A.N. (1966). Questionnaire design and attitude Measurement, Basic books, New York.

Roberto Rocha, \& Richard Hinz Joaquin Gutierrez. (1999). Improving the Regulation and Supervision of Pension Funds: are there lessons from the banking sector? The World Bank, Washington D.C, 1999, p.6.

Tilt, C. A. (2001). The Content and Disclosure of Australian Corporate Environmental Policies. Accounting, Auditing and Accountability, Vol.14, No.2, pp. 190-212. http://dx.doi.org/10.1108/09513570110389314

Weber, R. P. (1990). Basic Content Analysis, 2nd edition, Newbury Park, CA.

Yin, R. K. (2003). Case Study Research: Design and Methods, Third Edition, Thousand Oaks, CA: Sage Publication. 